Christos D. Dimopoulos, Nikolaos E. Karkalos, Angelos P. Markopoulos, Athens, Greece

\title{
STUDY ON MESH DEPENDENCE OF CUTTING ZONE DIMENSIONS PREDICTION DURING ABRASIVE WATERJET MACHINING
}

\begin{abstract}
Abrasive Waterjet Machining is a non-conventional material removal process, preferred to be used for the cutting of difficult-to-cut materials, due to its ability to remove material without the use of a tool and without causing heat affected zones. Experimentally, monitoring the phenomena taking place in the cutting area is very difficult, due to various reasons such as the high speed of the particles and the obstruction due to the water stream. Thus, a simulation approach, based on experimental data, is required in order to be able to explain these phenomena. In this work, a 3D thermo-mechanical Finite Element model is presented with realistic representation of the positioning of discrete abrasive particles and the dependence of cutting zone dimensions on the mesh size is investigated. After simulation, results are compared to experimental results, mesh independence study is conducted and finally, conclusions on the optimum mesh size are drawn and observed process characteristics are discussed.
\end{abstract}

Keywords: Abrasive Waterjet Machining, Non-conventional Machining, Finite Element Method.

\section{Introduction}

Non-conventional machining processes can be beneficial for the processing of hard-to-cut materials, such as hardened steel, titanium and nickel-based alloys or composites, because they do not involve the use of tools and can be applied to a wide range of materials [1]. More specifically, one of the most commonly used non-conventional processes is the Abrasive Waterjet Machining (AWJM), which involves material removal through high-speed impact of a waterjet containing abrasive particles. AWJM is a cold machining process, able to create even complex curves on hard workpieces, something that is frequently required in the aerospace and automotive industry [1,2].

AWJM is based on the principle of conversion of the energy of a highpressure water column to kinetic energy of a high-speed waterjet. As the waterjet cannot penetrate the surface of hard materials, the abrasive particles are added to the jet to improve its cutting capability. The abrasive particles flow towards the mixing chamber, where they are mixed and homogenized with the incoming high-speed water jet. Then, accelerated by the high-speed jet, a number of abrasive particles impact the workpiece surface and remove material, mainly by erosion. AWJM is an environment-friendly process, as no hazardous substances, coolant or lubricants are employed. Furthermore, due to the relatively low cutting forces during AWJM, there is no need for special clamping of the workpiece on the machine table. 
The types of materials machined by AWJM include metals, ceramics, alloys, polymers, composites, even textile and soft materials as plastic foams [1,3]. Important parameters for AWJM are the pressure and flow rate of the water jet, the traverse speed, the characteristics of the nozzle, the stand-off distance, the type and size of abrasive particles and the workpiece material $[1,4,5]$.

Although AWJM has been established for several decades, the understanding of material removal mechanisms and phenomena occurring during the process, are far from being complete. As it is not possible to conduct direct observations during the progress of AWJM, theoretical studies using appropriate numerical models are necessary, in order to be able to explain the occurring phenomena and improve its efficiency. Apart from theoretical approaches based on particle impact, such as the work of Finnie [6], or Zeng and Kim [7], numerical models using Finite Element Method (FEM) or meshless methods have also been presented. One of the earliest FEM approaches for modeling AWJM was conducted by Hassan and Kosmol [8], who created a single particle impact model for AWJM of a steel workpiece and investigated the dependence of depth of cut on pressure as well as its time evolution. Gudimetla and Yarlaggada [9] investigated the case of AWJM of a polycrystalline alumina workpiece with a single particle model. Using this model, they were able to predict erosion rate values close to the theoretical ones and observe the phenomena occurring during brittle erosion. Kumar and Shukla [10] presented a 3D FEM model for AWJM, including multiple steel particles in order to study the erosion process of Ti-6Al-4V for various impact angles and velocities. With this model they found that the variation of crater geometry with different particle velocities and angles was considerable for up to 17 impacts and then the variation was reduced or stabilized. Apart from simple FEM approaches, Wenjun et al. [11] and Shahverdi et al. [12] developed Arbitrary Lagrangian-Eulerian (ALE) models, in which the abrasive waterjet was explicitly modeled using an Eulerian mesh, while the workpiece was modeled using a Lagrangian formulation. Finally, Smoothed Particle Hydrodynamics (SPH) method has also been employed in the relevant literature, in order to model the abrasive particles flow [13] or even simulate their trajectory from the mixing chamber up to the workpiece surface [14].

In this paper, the dependence of AWJM simulation results on mesh size is investigated using a different modeling approach for AWJM, focusing on a more realistic abrasive particle positioning. The particles are modeled as discrete deformable bodies impacting the workpiece with a specific velocity depending on waterjet pressure. The simulation results are firstly compared to literature ones and then, mesh sensitivity analysis is carried out. Apart from mesh sensitivity study results, other significant results, such as the effect of 
process parameters on cutting zone dimensions, stress and temperature distribution are discussed as well.

\section{Methodology}

For the modeling of the AWJM, a 3D explicit FEM thermo-mechanical model was created in Abaqus. In order to investigate the effect of the mesh size on the results, three different meshes were used for three different experimental AWJM cases, described in [15], for a total of 9 simulation cases. The abrasive particles and workpiece were modeled using the Lagrangian formulation. Each abrasive particle consisted of a single rectangular C3D8RT mesh element and had diagonal dimension of $0.2 \mathrm{~mm}$ (Grit 80 ), while the rectangular shaped workpiece consisted of varying-size C3D8RT mesh elements, depending on the simulation case. The water is omitted in the present work, as it does not have the energy to cut the material on its own [16]; however, the effect of particle acceleration due to the waterjet was taken into account by a velocity boundary condition. The workpiece dimensions were $6 \mathrm{~mm}$ height, $4 \mathrm{~mm}$ length and 6 $\mathrm{mm}$ width, in the $\mathrm{y}, \mathrm{x}$ and $\mathrm{z}$ axes respectively, as can be also seen in Fig.1. The characteristics of the three different meshes used in this work, such as element size and number of elements are presented in Table 1.

Table 1 - Characteristics of the meshes employed in this work

\begin{tabular}{|c|c|c|c|}
\hline Mesh density & $\begin{array}{c}\text { Number of } \\
\text { elements }\end{array}$ & $\begin{array}{c}\text { Minimum element } \\
\text { size }(\mathrm{m})\end{array}$ & $\begin{array}{c}\text { Maximum } \\
\text { element size }(\mathrm{m})\end{array}$ \\
\hline Coarse & 67,320 & $10^{-4}$ & $3 \cdot 10^{-4}$ \\
\hline Average & 91,800 & $8 \cdot 10^{-5}$ & $2 \cdot 10^{-4}$ \\
\hline Fine & 210,120 & $4 \cdot 10^{-5}$ & $1 \cdot 10^{-4}$ \\
\hline
\end{tabular}

In order to position the abrasive particles in space, some calculations were carried out at first. Since the abrasive mass flow was constant at $2.56 \mathrm{~g} / \mathrm{s}$, the number of particles existing within the solution time was calculated. This was done by dividing the mass flow by the particle weight, multiplying that result with the final solution time of $1 \mathrm{~ms}$. After that, the distance between the particles was calculated, assuming that when a particle left the nozzle with a constant initial speed, the next one leaving the nozzle would have a fixed distance from the first one, based on the particle speed. Knowing the vertical distance between the particles and their total number, a Gaussian distribution was used for horizontal positioning of the particles, keeping them within the theoretical nozzle diameter of $0.3 \mathrm{~mm}$. The jet impact angle was $90^{\circ}$ and the initiation point was in the middle of the top left edge, with a standoff distance of $3 \mathrm{~mm}$. An initial vertical velocity was given to each particle per pressure case, and the same jet traverse speed was applied in all simulations. These were 
adopted from literature [15] and presented in Table 2. The selected material model for the workpiece material (AISI 1018 steel) was Johnson-Cook model [17], with the values related to plasticity and damage adopted from literature [18].
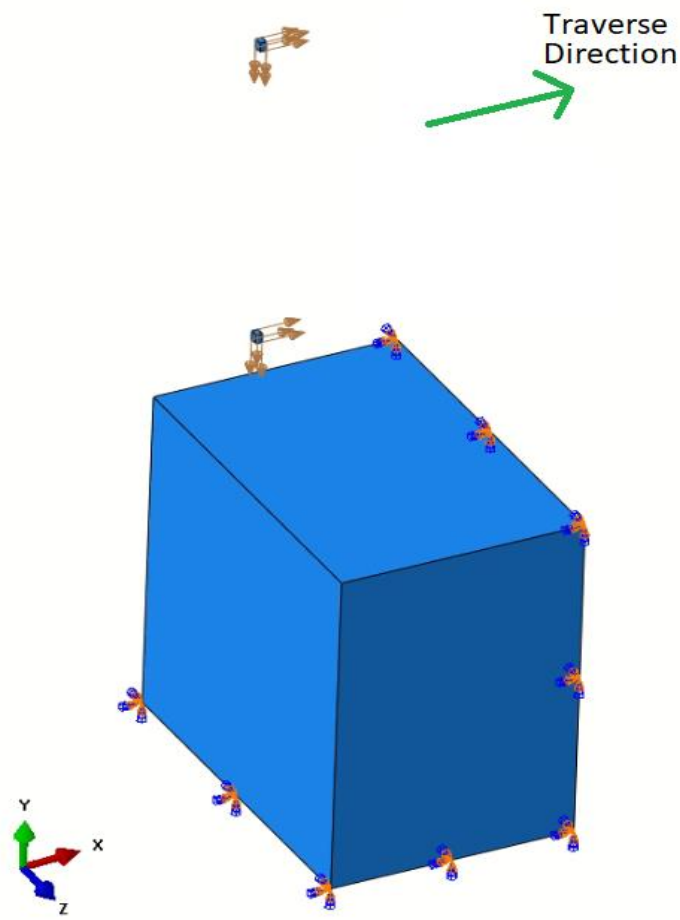

Figure 1 - AWJM model assembly

The abrasive particle mechanical and thermo-physical properties were adopted from literature as well [19]. Abrasive material was garnet, with a density value of $4,325 \mathrm{~kg} / \mathrm{m}^{3}$ and tensile failure stress was $150 \mathrm{MPa}$. A deletion criterion was adopted for the particles, to reduce computation time due to particle movement after collision with the workpiece; thus, when each particle reached the critical stress value of $150 \mathrm{MPa}$, it was deleted from the simulation. Furthermore, coefficient of friction between the particles and the workpiece was considered to be 0.1 . Due to high strain rates, adiabatic heating of the workpiece is considered, with a coefficient of $90 \%$, converting that percentage of plastic work done to heat [19], while initial model temperature was set to 
$20^{\circ} \mathrm{C}$. Finally, the workpiece was constrained at the bottom and right face, as shown in Fig. 1.

Table 2 - Waterjet pressure and abrasive particles velocity values for all simulation cases

\begin{tabular}{|c|c|c|}
\hline $\begin{array}{c}\text { Simulation } \\
\text { Case }\end{array}$ & Waterjet pressure (MPa) & Abrasive particle velocity (m/s) \\
\hline 1 & 100 & 400 \\
\hline 2 & 200 & 620 \\
\hline 3 & 350 & 810 \\
\hline
\end{tabular}

\section{Results and Discussion}

At first, simulation results were compared to experimental ones from the aforementioned literature reference [15]. In the present case, the simulation time of $1 \mathrm{~ms}$ was sufficient for the erosion process to start. By comparing the present simulation results to the experimental ones, the calculated forces never exceeded $1 \mathrm{~N}$, in accordance with the experimental results for the earliest stages of AWJM; thus, it can be assumed that the presented model is accurate enough.

Then, the investigation, regarding the dependence of simulation results on the mesh size took place. Results on predicted cutting zone dimensions for all cases are depicted in Fig. 2. It can be clearly observed that there exists a variation in the results, in respect to each type of mesh. The clearest difference is observed for the depth of cut in every case; in fact, a decrease of element size results in a visible increase of predicted depth of cut with the differences being more significant in the cases with particle speed of 400 and $620 \mathrm{~m} / \mathrm{s}$. The importance of using a sufficiently fine mesh for the simulation can be further stressed by observing that the use of a coarse mesh for the case with particle speed of $620 \mathrm{~m} / \mathrm{s}$ produced the same result with the simulation regarding the case with particle speed of $400 \mathrm{~m} / \mathrm{s}$ and a fine mesh, something that is not reasonable. As for traverse length and width of the cutting zone, there is not a definite trend in their variation with element size, except for some cases in which width was shown to decrease for finer meshes, so a clear conclusion cannot be deduced for them.

As the presented model is thermo-mechanical, it is considered important to observe the dependence of predicted temperature values on the mesh density. Maximum temperature observed in every simulation case is presented in Fig. 3. Starting from a maximum of $40^{\circ} \mathrm{C}$ for the lowest speed and rising to a maximum of $65^{\circ} \mathrm{C}$ for the highest speed, these results are in compliance with other experimental results of the same material [20]. Temperature is shown to increase as the mesh gets finer and as the abrasive particles' speed increases. Although temperature variation is relatively small in AWJM, its variation with 
mesh density is another indication that mesh density plays an important role for AWJM simulations.

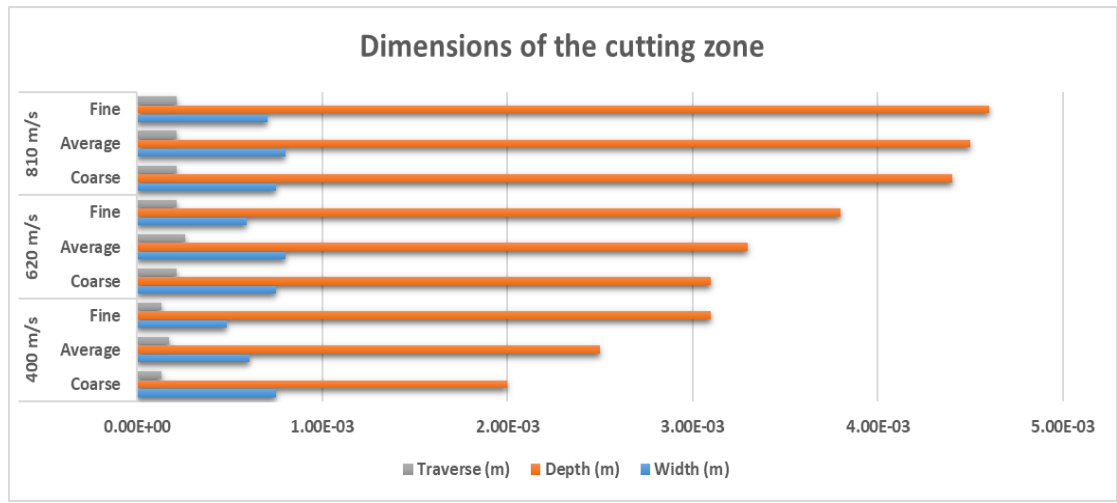

Figure 2 - Predicted dimensions of the cutting zone for all simulation cases

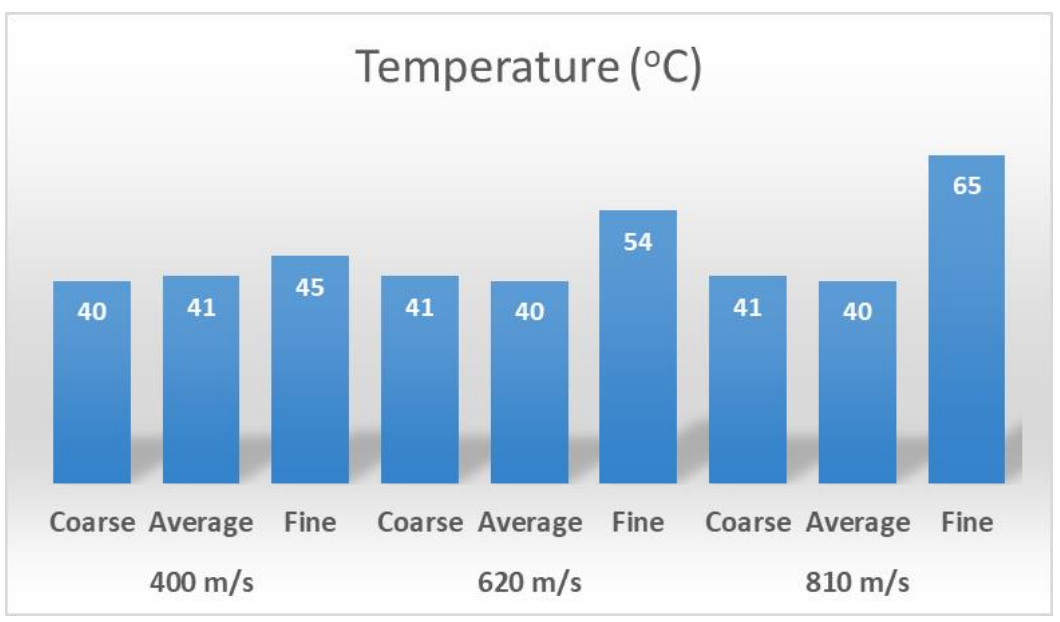

Figure 3 - Simulation temperature results for all cases

After the effect of mesh density on AWJM simulation results was determined, the results of the developed models can be further analyzed. Regarding depth of cut, a clearly increasing trend with increasing waterjet pressure was noted, as can be seen in Fig. 2, as expected from the experimental works [15]. Moreover, regarding workpiece temperature field, it is observed 
from relevant snapshots, such as the one in Fig.4, that temperature is considerably larger in the zone where erosion takes place and that there is minimal temperature change around the cutting zone.

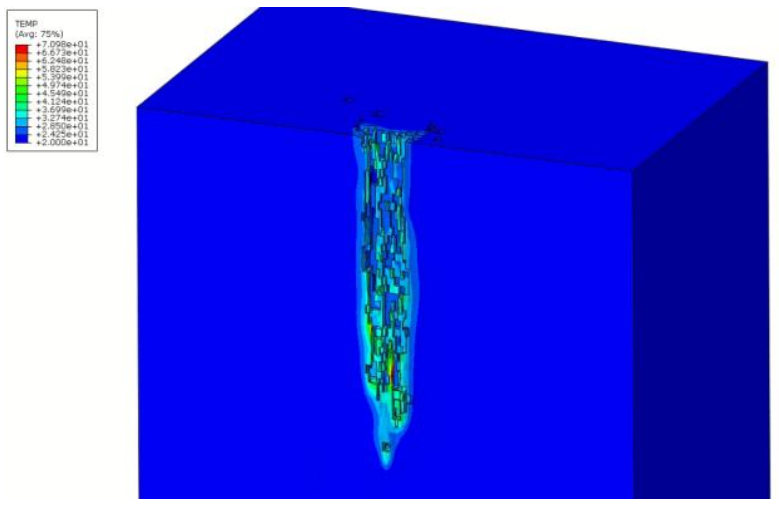

Figure 4 - Temperature distribution for finest mesh case at particle speed of $620 \mathrm{~m} / \mathrm{s}$

Furthermore, in Fig. 5 the von Mises stress distribution for the end of the simulation, for the finest mesh, at $810 \mathrm{~m} / \mathrm{s}$ particle speed is presented. Highest stress concentration is visible near the cutting zone, confirming theoretical expectations [20]. Another interesting observation is the material removal mechanism near the impact zone on the top face, where brittle erosion took place, since that area had no particle impact during the simulation.

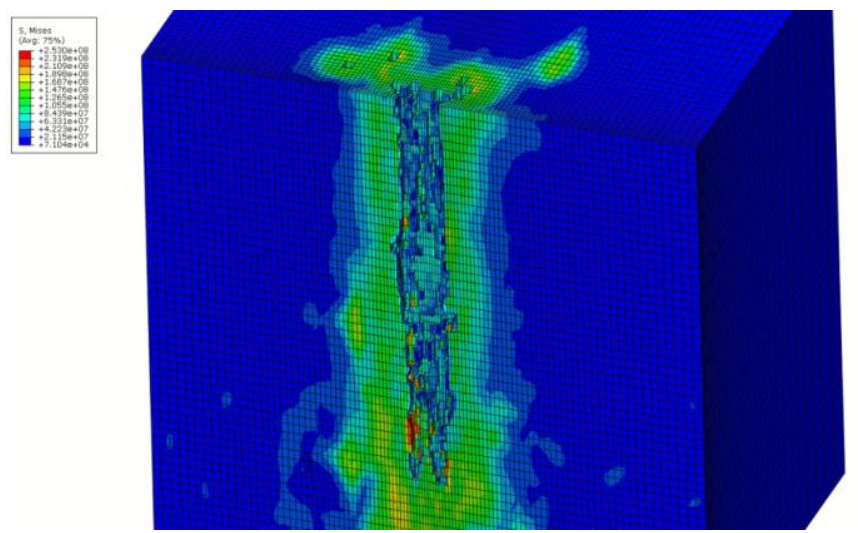

Figure 5 - Von Mises stress distribution for finest mesh case at $810 \mathrm{~m} / \mathrm{s}$ particle speed 
Finally, in Fig. 6 the time evolution of the cutting process for the fine mesh case at particle speed of $810 \mathrm{~m} / \mathrm{s}$ is presented. The view is cut along the width axis, so as the evolution of the erosion to be more easily understood. It is visible that the material is mainly removed in a vertical direction, with a few points of impact and deleted elements being occasionally in a distance from the main cutting zone during the evolution of the process.

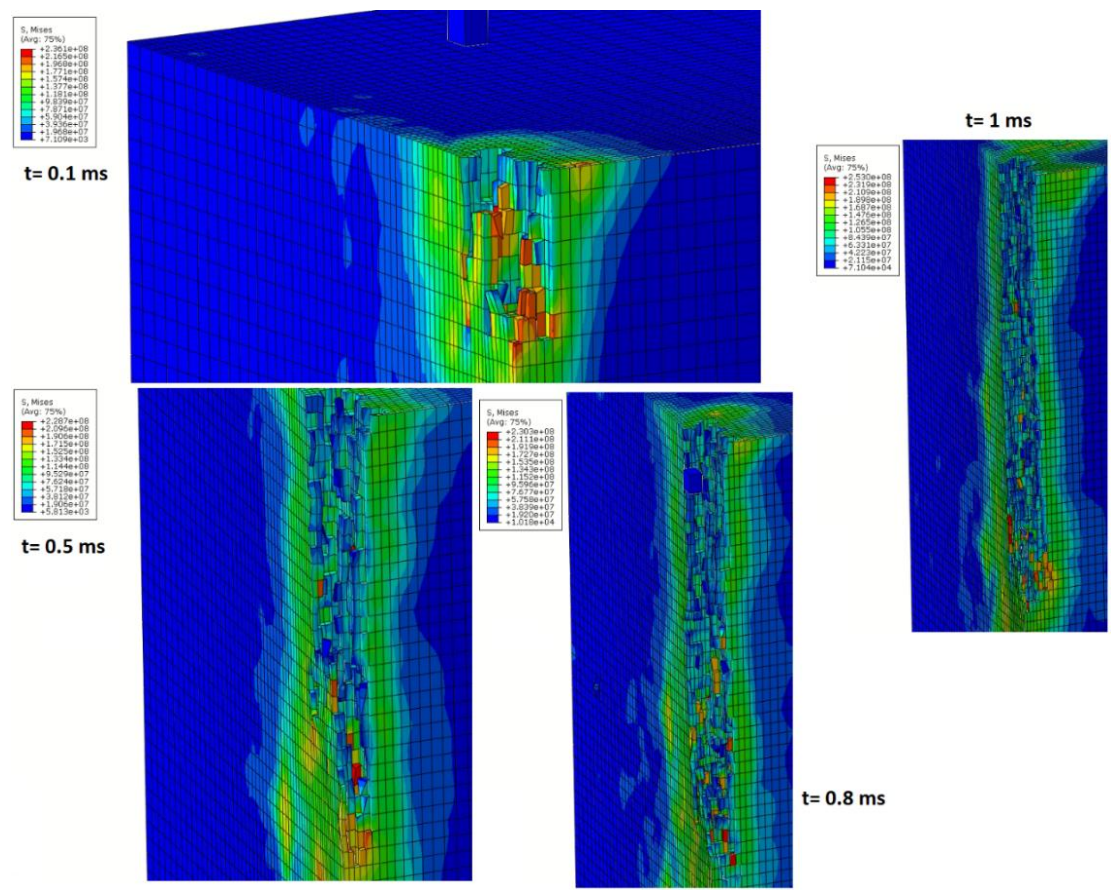

Figure 6 - Time evolution of the AWJM for the finest mesh at particle speed of $810 \mathrm{~m} / \mathrm{s}$

\section{Conclusions}

In the present paper, an investigation regarding the dependence of AWJM results on mesh element size was carried out. A 3D thermo-mechanical FEM model was developed with realistic positioning of abrasive particles, which were regarded as distinct deformable bodies. Simulations were carried out for three different waterjet pressure values with three different meshes and afterwards, the following conclusions were drawn:

- From the simulation results, it was deduced that there is a clear impact of mesh element size on predicted cutting zone dimensions. 
- Regarding depth of cut, the difference between meshes of different density were more obvious for the cases with particle speed of 400 and $620 \mathrm{~m} / \mathrm{s}$ and in every case, the depth of cut was higher for finer meshes.

- Regarding traverse length and width of cut, minimal variations were observed with different mesh element sizes.

- Furthermore, mesh size had a direct impact on workpiece maximum temperature, with predicted temperature being higher for finer meshes.

- Finally, the proposed model was able to predict experimentally observed trends of AWJM and thus it can be considered reliable for future studies.

References: 1. Kun-Bodnár, K., Kundrák, J.: Applicability of Waterjet Cutting for Different Machining Operations, Cutting \& Tools in Technological Systems 79, pp. 102-107. (2011). 2. KunBodnár, K., Maros, Z.: Theoretical Determination of Removed Layer Depth at Abrasive Waterjet Turning, Cutting \& Tools in Technological Systems 90, pp. 19-25. (2019). 3. Maros, Zs.: Machining of different materials with abrasive waterjet cutting, IOP Conference Series: Materials Science and Engineering 012009. (2018). 4. Maros, Zs.: Effect of load energy on the form of the gap at waterjet cutting, Key Engineering Materials 581, pp. 304-309. (2014). 5. Kun-Bodnár, K., Kundrák, J., Maros, Z.: Machining of rotationally symmetric parts with abrasive waterjet, IOP Conference Series: Materials Science and Engineering 448, 012053. (2018). 6. Finnie, I.: Erosion of Surfaces by Solid Particles, Wear 3, pp. 87-103. (1960). 7. Zeng,J., Kim,T.: An erosion model of polycrystalline ceramics in abrasive waterjet cutting, Wear 193, pp. 207-217. (1996). 8. Hassan, A.I., Kosmol, J.: Finite element modeling of Abrasive Water Jet Machining (AWJM), Proc. 15th International Conference on Jetting Technology, Ronnby, Sweden, pp. 321-333. (2000). 9. Gudimetla, P., Yarlagadda, P.K.D.V.: Finite element analysis of the interaction between an AWJ particle and a polycrystalline alumina ceramic, Journal of Achievements in Materials and Manufacturing Engineering 23(1), pp. 7-14. (2007). 10. Kumar, N., Shukla, M.: Finite element analysis of multi-particle impact on erosion in abrasive water jet machining of titanium alloy, Journal of Computational and Applied Mathematics 236(18), pp. 4600-4610. (2012). 11. Wenjun, G., Jianming, W., $\mathrm{Na}$, G.: Numerical simulation of abrasive water jet machining based on ALE algorithm, International Journal of Advanced Manufacturing Technology 53(1-4), pp. 247-253 (2011). 12. Shahverdi, H., Zohoor, M., Mousavi, S.M.: Numerical simulation of abrasive water jet cutting process using the SPH and ALE methods, International Journal of Advanced Design and Manufacturing Technology 5(1), pp. 43-50. (2011). 13. Jianming, W., Na, G., Wenjun, G.: Abrasive waterjet machining simulation by SPH method, International Journal of Advanced Manufacturing Technology 50 (1-4), pp. 227-234. (2010). 14. Feng, Y., Jianming, W., Feihong, L.: Numerical simulation of single particle acceleration process by SPH coupled FEM for abrasive waterjet cutting, International Journal of Advanced Manufacturing Technology 59 (1-4), pp. 193200. (2012). 15. Hassan, A.I., Chen, C., Kovacevic, R.: On-line monitoring of depth of cut in AWJ cutting, International Journal of Machine Tools and Manufacture 44(6), pp. 595-605. (2004). 16. Hassan, A.I., Kosmol, J.: Dynamic elastic-plastic analysis of 3D deformation in abrasive waterjet machining, Journal of Materials Processing Technology 113 (1-3), pp. 337-341. (2001). 17. Johnson, G.R., Cook, W.H.: A constitutive model and data for metals subjected to large strains, high strain rates and high temperatures, Proc. the 7th International Symposium on Ballistics (1983). 18. Buchely, M.F., Wang, X., Van Aken, D.C., O'Malley, R.J., Lekakh, S., Chandrashekhara, K.: The Use of Genetic Algorithms to Calibrate Johnson-Cook Strength and Failure Parameters of AISI/SAE 1018 Steel, Journal of Engineering Materials and Technology 141(2), 021012. (2018). 19. Anwar, S., Axinte, D.A., Becker, A.A.: Finite element modeling of abrasive waterjet milled 
footprints, Journal of Materials Processing Technology 213(2), pp. 180-193. (2013). 20. Momber, A.W., Kovacevic, R.: Principles of Abrasive Water Jet Machining, Springer-Verlag London (1998).

Христос Д. Дімопулос, Ніколаос Е. Каркалос, Ангелос П. Маркопулос, Афіни, Греція

\title{
ДОСЛІДЖЕННЯ ЗАЛЕЖНОСТІ ПРОГНОЗОВАНИХ РОЗМІРІВ ЗОНИ РІЗАННЯ ВІД ПАРАМЕТРІВ СІТКИ ПРИ АБРАЗИВНІЙ ВОДОСТРУМЕНЕВІЙ ОБРОБЦІ
}

\begin{abstract}
Анотація. Абразивна водоструменева обробка - ие нетрадиційний прочес видалення матеріалу, який краще використовувати для різання важкооброблюваних матеріалів через його здатності видаляти матеріал без використання інструменту $i$ без створення зон термічного впливу. Експериментально, моніторинг явищ, що відбуваються в зоні різання, дуже утруднений через різноманітні причини, такі як висока швидкість частинок $i$ перешкоди через потік води. Таким чином, імітачійний підхід, заснований на експериментальних даних, є найкращим для того, щуоб пояснити ці явища. У даній роботі представлена тривимірна кінцево-елементна термомеханічна модель з реалістичним поданням положення дискретних абразивних частинок $i$ досліджена залежність розмірів зони різання від розміру сітки. Після моделювання результати порівнюються $з$ експериментальними результатами, проводиться дослідження незалежності сітки $i$, нарешті, робляться висновки про оптимальний розмір сітки $i$ обговорюються характеристики прочесу, які спостерігаються. Моделювання проводилося для трьох різних значень тиску гідроабразивного струменю з трьома різними сітками, і після цього були зроблені висновки що, існує явний вплив розміру елементу сітки на прогнозовані розміри зони різання. Що стосується глибини різання, різниця між ячеями різної щільності була більш очевидною для випадків зі швидкістю частинок 400 i 620 м / c, $і$ в кожному випадку глибина різання була вище для більш дрібних ячей. Що стосується довжини і ширини обрізки, мінімальні зміни спостерігалися при різних розмірах елементів сітки. Крім того, розмір сітки безпосередньо вплинув на максимальну температуру заготовки, причому прогнозована температура була вище для більш дрібних сіток. Нарешті, запропонована модель була здатна передбачити експериментально спостережувані тенденції абразивної водоструменевої обробки (AWJM) i, таким чином, ї̈ можна вважати надійною для майбутніх досліджень.
\end{abstract}

Ключові слова: гідроабразивна обробка; нестандартна обробка; метод кінцевих елементів. 